\title{
Measuring TFP: Growth Accounting for the Real Sector of the Economy in the Republic of Srpska
}

\author{
Article history \\ Received: 29. May 2013 \\ Sent for revision: 21. June 2013 \\ Received in revised form: 02 . September 2013 \\ Accepted: 02. September 2013 \\ Available online: 06. November 2013
}

\begin{abstract}
This paper shows the results of research on contribution of Total Factor Productivity to the growth of the real sector in the Republic of Srpska. Total factor productivity is analytical tool which enables researchers to determine the contribution of supply-side production factors to economic growth. For the Republic of Srpska, which has a transition economy, it is a very difficult to construct a production function with stable and unbiased parameters, mostly because the lack of sufficiently long and dependable data series. Considering this, growth accounting enables us to identify the basic sources and direction of influences. The calculations that have been made enable researchers to identify the Total Factor Productivity as the main driving force of economic growth for the real sector in the Republic of Srpska.
\end{abstract}

Keywords: Total Factor Productivity, real growth, real sector of the economy, labour, capital.

\section{Merenje ukupne faktorske produktivnosti: računovodstvo rasta u realnom sektoru Republike Srpske}

Apstrakt: U ovom radu su prikazani rezultati istraživanja o doprinosu Ukupne Faktorske Produktivnosti na rast realnog sektora u Republici Srpskoj. Ukupna Faktorska Produktivnosti je analitički instrument koji omogućava istraživačima da se utvrdi doprinos faktora na strani ponude privrednom rastu. Za Republiku Srpsku, koja ima privredu u tranziciji, veoma je teško definisati proizvodnu funkciju sa stabilnim i nepristrasnim parametrima, uglavnom zbog nedostatka

\footnotetext{
${ }^{1}$ University of Banja Luka, Faculty of Economics, zoran.borovic@efbl.org

${ }^{2}$ University of Banja Luka, Faculty of Economics, darko.milunovic@efbl.org 
Borović Z. et al.: Measuring TFP: Growth Accounting for the Real Sector of the...

dovoljno duge i pouzdane serije podataka. Imajući to u vidu, "računovodstvo rasta" omogućava da prepoznamo osnovne izvore i pravac uticaja. Proračuni koje su urađeni identifikuju Ukupnu Faktorsku Produktivnost kao glavni pokretač rasta realnog sektora u Republici Srpskoj.

Ključne reči: Ukupna Faktorska Produktivnost, realni rast, realni sektor privrede, rad, kapital.

\section{Introduction}

The assessment of the economic development of the Republic of Srpska (RS) since the middle of the 1990s is not easy. The beginning of the transition process is characterized with poor privatization which led to low level of economic activity which eventually led to a loss of economic welfare compared to the previous decades.

Throughout the post-war period in Bosnia and Herzegovina there has been an active currency board and the economy of RS has been characterized by real GDP growth. The value of this growth is $5 \%$ or more on an annual basis. The main goal of this paper is to find an answer to the question: Which are the driving forces of real sector economic growth, considering the shortcomings in form of insufficiently long time series.

In this paper we will evaluate the contribution of the supply-side production factors to the real sector of economic growth of the RS for the period 20042010. The accent is put on analysis of the contribution of Total Factor Productivity (TFP) (which is considered a measure of changes in the quality of the production process) to the real sector of the economy. TFP is sometimes called the Solow residual after Robert Solow, who first showed how to compute it (Solow, 1957).

Throughout period of transition the increase of total factor productivity contains the influence of other substantial factors. Firstly, the increase reflects the influence of financial stability, which is a result of the currency board arrangements since 1995. Second, the increase is a result of building of institutions necessary for the normal modern functioning of market economies which play a significant role in the management of macroeconomic processes. The approach that has been used here in the measurement of TFP is the socalled growth accounting.

In macroeconomic analysis the TFP concept does not have a stand-alone meaning, until the influence of capital and labour is taken into consideration (and also other factors, for which statistics are available). The calculation of total factor productivity in addition to the contributions of labour and capital 
Borović Z. et al.: Measuring TFP: Growth Accounting for the Real Sector of the...

indicates an inability to identify or quantify the remaining objectively existing factors which determine economic growth. Very often, this inability is the consequence of lack of suitable statistical data or from the lack of preliminary studies of the values of other factors which determine economic growth. After identifying the influence of the production factors for which we have available statistical data, all that remains is the contribution of all other factors, which are generalized with the term TFP. When the calculation of the increase of the total factor productivity is finished by using data on capital and labour the analysis is incomplete by definition, because there are more than two factors of growth identified in modern theory and empirics of economic growth. In the current paper the factor 'human capital' is missing, while it is expected to make a significant contribution. The growth accounting is not the only approach in economic literature for the identification of factors and their contribution. Econometric estimation is very often used to estimate factor contribution. In the present case this approach has not been chosen since it is characterized by certain shortcomings. Restriction in the present case stems mostly from the fact that the available annual data on income formation by economic sector do non cover a long enough, and would not lead to stable and unbiased parameters from regression analysis.

\section{Model}

Growth accounting provides a insight into components associated with changes in factor inputs and a residual that reflects technological progress and other elements. The basics of growth accounting were presented in Solow (1956 and 1957). The Solow growth model presents a theoretical framework for understanding the sources of economic growth, and the consequences for long term growth of changes in the economic environment and in economic policy. Solow model belongs to the neoclassical model of economic growth. The basic assumptions of the neoclassical growth model is a competitive market and constant returns to scale. The foundation of the neoclassical growth model is a neoclassical production function (Solow, 1957):

$Y=f(K, L, A)$

where $Y$ is the volume of production, $K$ is capital, $L$ is labour and $A$ is Hicks neutral technical progress. Change in production volume can be determined by changing the labour or capital, or changing their productivity, or change in technical progress. Sources of changes in the volume of production (or total differential) can be written as: 
Borović Z. et al.: Measuring TFP: Growth Accounting for the Real Sector of the...

$d Y=\frac{\partial Y}{\partial K} d K+\frac{\partial Y}{\partial L} d L+\frac{\partial Y}{\partial A} d A$

With some algebraic rearrangement exspression (2) becomes:

$\frac{d Y}{Y}=\frac{\partial Y}{\partial K} \frac{K}{Y} \frac{d K}{K}+\frac{\partial Y}{\partial L} \frac{L}{Y} \frac{d L}{L}+\frac{\partial Y}{\partial A} \frac{A}{Y} \frac{d A}{A}$

In other words:

$\frac{d Y}{Y}=\varepsilon_{Y, K} \frac{d K}{K}+\varepsilon_{Y, L} \frac{d L}{L}+\varepsilon_{Y, A} \frac{d A}{A}$

In this way we have a growth rate of output displayed as the weighted average growth rate of capital, labour and technical progress, where the weights are the elasticity of production by capital, labour and technical progress. Suppose that the real wages and real interest rates equal the marginal productivity of labour and capital, ie. (Solow, 1956),

$\frac{\partial Y}{\partial L}=\frac{W}{P}$ and $\frac{\partial Y}{\partial K}=\frac{r}{P}$,

then we can write expression (3) as:

$\frac{d Y}{Y}=\frac{r K}{P Y} \frac{d K}{K}+\frac{W L}{P Y} \frac{d L}{L}+\frac{\partial Y}{\partial A} \frac{d A}{Y}$

In the case of the Cobb-Douglas function we have

$Y=A K^{\alpha} L^{1-\alpha}$

First, take logs from expression (6):

$\log Y_{t}=\log \left(A_{t} K_{t}^{\alpha} L_{t}^{1-\alpha}\right)$

$\log Y_{t}=\log A_{t}+\log K_{t}^{\alpha}+\log L_{t}^{1-\alpha}$

$\log Y_{t}=\log A_{t}+\alpha \log K_{t}+(1-\alpha) \log L_{t}$

Repeat this for time $t+1$ and take diferences:

$\log Y_{t+1}=\log A_{t+1}+\alpha \log K_{t+1}+(1-\alpha) \log L_{t+1}$

$\Delta \log Y_{t}=\Delta \log A_{t}+\alpha \Delta \log K_{t}+(1-\alpha) \Delta \log L_{t}$ 
Borović Z. et al.: Measuring TFP: Growth Accounting for the Real Sector of the...

Finally, we use the approximation $\Delta \log (\mathrm{x}) \approx \% \Delta(\mathrm{x})$ :

$$
\frac{d Y}{Y}=\frac{d A}{A}+\alpha \frac{d K}{K}+(1-\alpha) \frac{d L}{L}
$$

Since $\alpha<1$, then $1-\alpha<1$, which means that increase in technical progress by $1 \%$ will have a greater impact on the growth of output than increase in labour or capital by $1 \%$. In the Cobb-Douglas production function a represents the share of capital in the actual level of production or in the realized GDP. The share capital in realized GDP $(\alpha)$ is defined as (Solow, 1956):

$$
\alpha=\frac{\partial Y}{\partial K} \frac{K}{Y}
$$

Share of labour is defined as (Ibidem):

$$
(1-\alpha)=\frac{\partial Y}{\partial L} \frac{L}{Y}
$$

The labor share is a key indicator for the distribution of income in a country. It shows how much of national income is distributed to labor and how much to capital. The capital share includes all non-labor income including interest income and economic profit which can be added together and be defined as accounting profit. One way to calculate share of labour is (Lipsey \& Carlaw, 2001):

$$
(1-\alpha)=\frac{\sum \frac{W}{P}}{G D P}
$$

The expression above fraction is the total amount of paid real gross wages. $\mathrm{W}$ is total amount of paid gross wages and $P$ is price index with base in 2001 . Based on the determined participation of labour it is easily to identify share of capital. US Bureau of Labor Statistics uses expression (13) to calculate share of labour (Gomme \& Rupert, 2004):

$$
(1-\alpha)=\frac{L C}{G V A}
$$

where LC is Labour Compensation. LC is similar to COE (Compensation Of Employees) COE Compensation of employees consists of gross wages and salaries, including employees' taxes and social contribution. For simplicity and 
Borović Z. et al.: Measuring TFP: Growth Accounting for the Real Sector of the...

availability of data for calculating the share of labour we will use exspression (13).

First problem in our research is to estimate volume of capital. Data on capital are not published by official statistics and it requires additional calculation. The most commonly used method for capital assessment is the so-called 'perpetual inventory method' (PIM), which can be described briefly with the equation: (Burda \& Severgnini, 2008):

$$
K_{t}=I_{t}+(1-\delta) K_{t-1}
$$

where $K_{t}$ is the volume of capital at time $t, I_{t}$ is the volume of investments made at time $\mathrm{t}$ and $\delta$ is the depreciation rate. The PIM method simply integrates the Goldsmith equation (Goldsmith, 1955). Our second problem is to determine the amount of the initial or start-up capital. The initial volume of capital is calculated using the following form (Ganev, 2005,):

$$
K_{0}=\frac{I_{0}}{\delta}
$$

$\mathrm{I}_{0}$ and $\mathrm{K}_{0}$ have the same meaning as in the previous form, but this time related to the initial period. Here we assume that $\delta=0.05$, which means that the full depreciation of a given capital unit takes place within 20 years. The choice of this value is based on estimates found in many other surveys. Some of these studies are Hernandez and Mauleon (2003) for the economy of Spain, Cororaton (2002) for the Philippines, Felipe (1997) for a group of countries in East Asia, etc. Transformation of the expression (13) gives the final equation for capital stock (lbidem):

$$
K_{t}=\sum_{i=0}^{n-1}(1-\delta)^{i} I_{t-i}+(1-\delta)^{n} K_{t-n}
$$

where $\mathrm{n}$ represents the fixed moment in time, from which we take the initial capital stock. The current capital stock is the weighted sum of an initial capital value, $\mathrm{K}_{0}$, and intervening investment expenditures, with weights corresponding to their undepreciated components (Burda, et al, 2008). Four general problems arise from using capital stock data estimated by statistical agencies. The first problem is assessment of initial capital. The construction of capital stock requires an accurate measurement of the initial capital. The shorter time series is, it is more likely that calculation of capital stock would be inaccurate and will affect the construction of the Solow residual. The second problem is to separate truly utilized capital at any point of time from that which 
is idle. In 1957 Solow suggested that the appropriate measurement should be of "capital in use, not capital in place". The third problem is to apply an appropriate depreciation rate for some sectors and some types of capital. This is a very difficult and almost impossible, especially for the retail sector. The fourth problem is the omission of many intangible inputs such as research and development expenditures and goodwill from the measurement of capital. Applying the Goldsmith equation implies that inaccurate calculation of initial capital will lead to mismeasurement of current capital stock, which will eventually lead to inaccurate calculation of the Solow residual. This problem can only be solved with sufficiently long time series which will push initial condition sufficiently back into the past. With the exception of a few countries it is impossible to a find sufficiently long time series for investment. The RS is a country in transition and there is a limitation of the data that were analyzed. The US Bureau of Economic Analysis (BEA) assumes that investment in the initial period $\mathrm{I}_{0}$, represents the steady state in which expenditures grow at rate $g$ and are depreciated at rate $\delta$, so a natural estimate of $K_{0}$ is given by (Burda, et al, 2008):

$$
K_{0}=I_{0}\left(\frac{1+g}{\delta+g}\right)
$$

In modern theories of growth most of the attention is paid to the contribution of technical progress to economic growth. It is assumed that technical progress is not an exogenous variable but depends on education and research and development. Hence, the recent theory called endogenous growth theory. The contribution of technical progress is calculated indirectly based on expression (9) (Solow, 1957.):

$$
\frac{d A}{A}=\frac{d Y}{Y}-\left[\alpha \frac{d K}{K}+(1-\alpha) \frac{d L}{L}\right]
$$

The expression (18) presents the effect of TFP increase to economic growth, i.e. the part of economic growth which is not a consequence of capital stock and employment increase, but of their productivity (Petrovi, 2012). The Solow residual is the change in output that cannot be explained by changes in inputs. Transformation of the expression (9) gives a growth rate of output per employee (Ibidem):

$$
\frac{d Y}{Y}-\frac{d L}{L}=\frac{d A}{A}+\alpha\left[\frac{d K}{K}-\frac{d L}{L}\right]
$$


Borović Z. et al.: Measuring TFP: Growth Accounting for the Real Sector of the...

The expression (18) decomposes labour productivity growth into two components. The first component $\alpha\left[\frac{d K}{K}-\frac{d L}{L}\right]$ tells us what is the contribution of capital deepening to growth in labour productivity. The second component $\frac{d A}{A}$ tells us what is the contribution of TFP to productivity growth.

\section{Analysis of the Real Sector in the RS}

The economy of the RS is divided into the following activities ${ }^{3}$

- A - agriculture, hunting, and forestry;

- $\quad$ B - fishery;

- $\quad$ C - mining and quarrying;

- D - manufacturing;

- $\quad$ E - electricity, gas, and water supply;

- F - construction;

- $\quad$ G - wholesale and retail trade;

- $\quad \mathrm{H}$ - hotels and restaurants;

- I - transport, storage, and communications;

- $\mathrm{J}$ - financial intermediation;

- $\quad \mathrm{K}$ - real estate, renting, and business activities;

- $\quad$ L - public administration and defence, compulsory social security;

- $\quad$ M - education;

- $\quad \mathrm{N}$ - health and social work;

- $\quad$ O - other community, social, and personal serivce activities.

In this paper we will focus on the real sector of the economy, which should be the basis of economic growth. The analysis will focus on sectors $A, C, D, E$ and $F$. These sectors create new value and should be the backbone of economic growth. The basic assumptions of the neoclassical growth model are not fully met. The assumption of a competitive market does not apply to certain market segments in the RS. For example, there is only one legal entity that performs the production and distribution of electricity. We start with an overview of the participation of sectoral real Gross Value Added (GVA) and rates of growth of real GVA. Real growth rates obtained by the author differ from those published by official statistics. The real GVA is expressed in previous year prices. ${ }^{4}$

\footnotetext{
${ }^{3}$ http://rzs.rs.ba/Publikacije/NacionalniRacuni/Bilten Nacionalni Racuni 4.pdf

4 http://rzs.rs.ba/Publikacije/NacionalniRacuni/Bilten Nacionalni Racuni 4.pdf
} 
Borović Z. et al.: Measuring TFP: Growth Accounting for the Real Sector of the...

Hypothetically, if we want to determine the real growth rate for an economy which produces only one product and real GVA is calculated at prices of one base year, we will use the following form:

$$
\frac{Q_{t} * P_{b}}{Q_{t-1} * P_{b}}
$$

where $Q_{t}$ is output in year $t, Q_{t-1}$ output in the previous year, and $P_{b}$ are base year prices. Based on expressions (19) by cancelling out the same values we obtain the actual growth rate. If we want to determine the real growth rate for our hypothetical example between 2012 and 2011 applying methodology of the official statistics in RS, then we use the following form:

$$
\frac{Q_{012} * P_{11}}{Q_{011} * P_{10}}
$$

where $Q_{012}$ is output in year 2012, $Q_{011}$ output in previous year (year 2011.), $P_{11}$ is price level in 2011, and $P_{10}$ is price level in 2010. Based on expression (24) it is clear that the real growth rate incorporates the rate of price growth in 2011 compared to the 2010 . This calculation does not reflect the real state of things and shows real growth higher than it actually is. It is necessary to exclude the effect of price growth. This is achieved by simply multiplying the expression (24) with the reciprocal of the price index in 2011

$$
\frac{Q_{012} * P_{11}}{Q_{11} * P_{10}} * \frac{P_{10}}{P_{11}}
$$

By cancelling out the same values we obtain the actual growth rate. The real growth rate can be calculated in a similar way: we simply multiply real GVA published in official statistics by the reciprocal value of the price index with a base in 2001. Then we calculate the growth rate with these values:

$$
\left[\frac{\left(Q_{11} * P_{10}\right) * \frac{P_{01}}{P_{10}}}{\left(Q_{10} * P_{09}\right) * \frac{P_{01}}{P_{09}}}\right] \Rightarrow \frac{Q_{11} * P_{01}}{Q_{10} * P_{01}}
$$

A review of the structure and real GVA growth rate is given in Table 1. 
Borović Z. et al.: Measuring TFP: Growth Accounting for the Real Sector of the...

Table 1. The structure and growth rate of real GVA in the real sector in RS

\begin{tabular}{|c|c|c|c|c|c|c|c|c|c|}
\hline \multirow{2}{*}{ Sectors } & \multicolumn{9}{|c|}{ Years (GVA Structure) } \\
\hline & 2002 & 2003 & 2004 & 2005 & 2006 & 2007 & 2008 & 2009 & 2010 \\
\hline $\begin{array}{l}\text { Real } \\
\text { Sector }\end{array}$ & $44 \%$ & $39 \%$ & $40 \%$ & $43 \%$ & $44 \%$ & $41 \%$ & $42 \%$ & $40 \%$ & $39 \%$ \\
\hline$A$ & $19 \%$ & $16 \%$ & $15 \%$ & $17 \%$ & $16 \%$ & $17 \%$ & $16 \%$ & $14 \%$ & $13 \%$ \\
\hline $\mathrm{C}$ & $2 \%$ & $1 \%$ & $2 \%$ & $2 \%$ & $3 \%$ & $2 \%$ & $2 \%$ & $2 \%$ & $2 \%$ \\
\hline $\mathrm{D}$ & $11 \%$ & $11 \%$ & $11 \%$ & $12 \%$ & $13 \%$ & $11 \%$ & $11 \%$ & $11 \%$ & $12 \%$ \\
\hline$E$ & $5 \%$ & $5 \%$ & $7 \%$ & $7 \%$ & $7 \%$ & $5 \%$ & $6 \%$ & $6 \%$ & $6 \%$ \\
\hline $\mathrm{F}$ & $7 \%$ & $6 \%$ & $6 \%$ & $6 \%$ & $5 \%$ & $6 \%$ & $8 \%$ & $7 \%$ & $6 \%$ \\
\hline \multirow{2}{*}{ Sectors } & \multicolumn{9}{|c|}{ Years (GVA real growth rate) } \\
\hline & 2002 & 2003 & 2004 & 2005 & 2006 & 2007 & 2008 & 2009 & 2010 \\
\hline Economy & $8 \%$ & $9 \%$ & $7 \%$ & $11 \%$ & $6 \%$ & $2 \%$ & $\% 9$ & $\% 2$ & $3 \%$ \\
\hline $\begin{array}{c}\text { Real } \\
\text { sector }\end{array}$ & $2 \%$ & $-3 \%$ & $10 \%$ & $20 \%$ & $8 \%$ & $-4 \%$ & $12 \%$ & $-3 \%$ & $-1 \%$ \\
\hline$A$ & $11 \%$ & $-11 \%$ & $4 \%$ & $22 \%$ & $3 \%$ & $3 \%$ & $3 \%$ & $-9 \%$ & $-1 \%$ \\
\hline$C$ & $-11 \%$ & $-4 \%$ & $35 \%$ & $15 \%$ & $65 \%$ & $-22 \%$ & $27 \%$ & $-7 \%$ & $1 \%$ \\
\hline $\mathrm{D}$ & $1 \%$ & $5 \%$ & $7 \%$ & $29 \%$ & $8 \%$ & $-9 \%$ & $8 \%$ & $2 \%$ & $9 \%$ \\
\hline$E$ & $-19 \%$ & $14 \%$ & $36 \%$ & $12 \%$ & $8 \%$ & $-20 \%$ & $14 \%$ & $11 \%$ & $3 \%$ \\
\hline $\mathrm{F}$ & $6 \%$ & $-3 \%$ & $2 \%$ & $10 \%$ & $2 \%$ & $16 \%$ & $37 \%$ & $-6 \%$ & $-6 \%$ \\
\hline
\end{tabular}

Source: Author's calculations

The average share of the real sector in total GVA for the period was $41 \%$, while sectors $A$ and $D$ have the largest share in the real sector, $16 \%$ and $11 \%$ respectively. The share of the real sector has decreased by five percentage points. For the Republic of Serbia, in 2001 share if inustry (industry is by its structure simillar to real sector) in GVA was $24 \%$, while in 2010 it fel to $20.9 \%$ (Leković \& Mićić, 2013). Sector $C$ has the lowest share, 2\% on average annually. Other sectors achieved a share of $6 \%$ on average. Just for comparison, sector $L$ (public administration and defence, compulsory social security) has achieved an average share of $10 \%$ on average for the period. The average growth rate of total GVA in the period was $6 \%$. The analysed data shows negative growth rates for some sectors. The real sector achieved an average growth rate of $5 \%$. The highest average growth rate of $11 \%$ is achieved by sector $\mathrm{C}$, while sectors $\mathrm{A}, \mathrm{D}, \mathrm{E}$, and $\mathrm{F}$ achieved the following average rates respectively: $5 \%, 7 \%, 6 \%$ and $6 \%$. By comparison sector $L$ has an average real growth rate of $11 \%$. Sector $L$ achieves a higher share in total GVA and a higher growth rate than the sectors that should be the backbone of economic growth. This is an anomaly. 
Borović Z. et al.: Measuring TFP: Growth Accounting for the Real Sector of the...

We continue the review with an analysis of real net average wages by sector. Purchasing power in Table 2 is expressed in the constant prices with base in 2001.

Table 2. Real net average wages

\begin{tabular}{|c|c|c|c|c|c|c|c|c|c|c|}
\hline \multirow{2}{*}{ Sectors } & \multicolumn{10}{|c|}{ Years } \\
\cline { 2 - 12 } & 2001 & 2002 & 2003 & 2004 & 2005 & 2006 & 2007 & 2008 & 2009 & 2010 \\
\hline $\begin{array}{c}\text { Annuall } \\
\text { average }\end{array}$ & 309 & 341 & 364 & 397 & 423 & 433 & 477 & 574 & 602 & 584 \\
\hline A & 259 & 312 & 325 & 349 & 363 & 370 & 421 & 470 & 462 & 434 \\
\hline C & 260 & 198 & 235 & 317 & 374 & 500 & 562 & 646 & 682 & 703 \\
\hline D & 210 & 231 & 249 & 284 & 312 & 315 & 354 & 373 & 400 & 410 \\
\hline E & 427 & 483 & 497 & 516 & 558 & 563 & 571 & 630 & 708 & 685 \\
\hline F & 216 & 261 & 279 & 319 & 352 & 347 & 395 & 408 & 421 & 413 \\
\hline L & 488 & 554 & 568 & 622 & 647 & 642 & 724 & 778 & 826 & 779 \\
\hline
\end{tabular}

Source: Author's calculations

The purchasing power of workers in the RS grew by $7.3 \%$ per year not nearly $11 \%$ as shown in official statistics. Sectors A, C, D, E, and F have realized average growth rates of $5.9 \%, 11.7 \%, 7.7 \%, 5.3 \%, 7.4 \%$, and $5.3 \%$ respectively. All real sectors except Sector $E$ have an average salary which is $80 \%$ of the average wage for the RS. Sector $L$ has an average salary which is $40 \%$ higher than the average salary in RS. During the last ten years sector L has twice the purchasing power of sector $D$ on average. This is another anomaly.

The unemployment problem is one of the biggest in the RS. Table 3 provides an overview of employment by sector.

Table 3. Employees by sector for the RS - relative share

\begin{tabular}{|l|r|r|r|r|r|r|r|r|r|r|}
\hline \multirow{2}{*}{ Sectors } & \multicolumn{10}{|c|}{ Years } \\
\cline { 2 - 11 } & 2001 & 2002 & 2003 & 2004 & 2005 & 2006 & 2007 & 2008 & 2009 & 2010 \\
\hline $\begin{array}{l}\text { Real } \\
\text { sector }\end{array}$ & $46 \%$ & $44 \%$ & $42 \%$ & $39 \%$ & $37 \%$ & $34 \%$ & $33 \%$ & $37 \%$ & $36 \%$ & $35 \%$ \\
\hline A & $4 \%$ & $4 \%$ & $4 \%$ & $4 \%$ & $3 \%$ & $3 \%$ & $3 \%$ & $3 \%$ & $3 \%$ & $4 \%$ \\
\hline C & $2 \%$ & $2 \%$ & $2 \%$ & $1 \%$ & $1 \%$ & $1 \%$ & $2 \%$ & $2 \%$ & $2 \%$ & $2 \%$ \\
\hline D & $30 \%$ & $28 \%$ & $27 \%$ & $25 \%$ & $23 \%$ & $21 \%$ & $20 \%$ & $23 \%$ & $21 \%$ & $20 \%$ \\
\hline E & $4 \%$ & $4 \%$ & $4 \%$ & $4 \%$ & $4 \%$ & $4 \%$ & $3 \%$ & $4 \%$ & $4 \%$ & $4 \%$ \\
\hline F & $5 \%$ & $6 \%$ & $5 \%$ & $5 \%$ & $5 \%$ & $5 \%$ & $5 \%$ & $6 \%$ & $6 \%$ & $5 \%$ \\
\hline L & $9 \%$ & $9 \%$ & $9 \%$ & $8 \%$ & $8 \%$ & $8 \%$ & $8 \%$ & $8 \%$ & $9 \%$ & $9 \%$ \\
\hline
\end{tabular}

Source: Author's calculations 
Borović Z. et al.: Measuring TFP: Growth Accounting for the Real Sector of the...

During the last ten years employment in the real sector declined by eleven percentage points, which represent a decrease of $2 \%$ average annually. Most employees lost their jobs in sector D. The participation of sector $D$ in total employment fell by ten percentage points, which represents a decline of $4 \%$ annually. Most workers are employed in sector D, on average $24 \%$. Sector L has more employees than any other sector, except Sector D.

Investmetns are important component increasing the volume of production. They affect the growth of capital and increase worker productivity. Data on investments are calculated in constant prices with a base in 2001 . Due to objective limitations, data on investments are available only for the period 2004-2010 and are presented in Table 4.

Table 4. Relative investment structure for the $R S$

\begin{tabular}{|l|r|r|r|r|r|r|r|}
\hline \multirow{2}{*}{ Sectors } & \multicolumn{7}{|c|}{ Years } \\
\cline { 2 - 8 } Real sector & 2004 & 2005 & 2006 & 2007 & 2008 & 2009 & 2010 \\
\hline A & $46 \%$ & $38 \%$ & $36 \%$ & $29 \%$ & $31 \%$ & $35 \%$ & $33 \%$ \\
\hline C & $2 \%$ & $2 \%$ & $3 \%$ & $2 \%$ & $2 \%$ & $3 \%$ & $3 \%$ \\
\hline D & $14 \%$ & $16 \%$ & $15 \%$ & $15 \%$ & $17 \%$ & $17 \%$ & $13 \%$ \\
\hline E & $21 \%$ & $13 \%$ & $11 \%$ & $7 \%$ & $5 \%$ & $9 \%$ & $11 \%$ \\
\hline F & $6 \%$ & $4 \%$ & $4 \%$ & $4 \%$ & $5 \%$ & $4 \%$ & $4 \%$ \\
\hline L & $12 \%$ & $17 \%$ & $28 \%$ & $36 \%$ & $25 \%$ & $27 \%$ & $29 \%$ \\
\hline
\end{tabular}

Source: Author's calculations

The participation of the real sector in total investment fell by ten percentage points, which is a decrease of $5.11 \%$ on average annually. The participation of sector $L$ grew on average by $15.7 \%$ annually. The participation of sectors $E$, $\mathrm{F}$, and $\mathrm{C}$ was reduced by $10.23 \%, 6.4 \%$ and $2.4 \%$ on average per year, respectively. Sector $L$ has almost the same share in investments as a real sector.

Using expressions (13) and (16) we calculate the amount of capital stock. With data on capital stock we obtain labour and capital productivity. 
Borović Z. et al.: Measuring TFP: Growth Accounting for the Real Sector of the...

Table 5. Capital stock, labour and capital productivity

\begin{tabular}{|c|c|c|c|c|c|c|c|c|c|}
\hline Years & 2002 & 2003 & 2004 & 2005 & 2006 & 2007 & 2008 & 2009 & 2010 \\
\hline $\mathrm{K}$ & na & na & 5943299 & 5991152 & 5980213 & 6008832 & 6125874 & 6230395 & 6278047 \\
\hline $\mathrm{K} / \mathrm{L}$ & na & na & 64,12 & 66,27 & 70,78 & 71,03 & 63,79 & 66,81 & 73,92 \\
\hline $\mathrm{Q} / \mathrm{L}$ & 13,84 & 14,28 & 16,64 & 20,49 & 20,71 & 22,60 & 22,32 & 22,31 & 24,28 \\
\hline $\mathrm{Q} / \mathrm{K}$ & na & na & 0,26 & 0,31 & 0,29 & 0,32 & 0,35 & 0,33 & 0,33 \\
\hline $\mathrm{MPK}$ & na & na & $\mathrm{Na}$ & 6,47 & 9,33 & 5,65 & 1,98 & $-0,60$ & $-0,38$ \\
\hline $\mathrm{MPL}$ & na & 3,15 & $-24,60$ & $-134,99$ & 17,27 & 1554,23 & 20,22 & 22,53 & 2,20 \\
\hline
\end{tabular}

Source: Author's calculations

The growth rate of capital is $0.8 \%$ on average annually. Data on capital $\mathrm{K} / \mathrm{L}$, $\mathrm{Q} / \mathrm{L}$ and $\mathrm{Q} / \mathrm{K}$ are in thousands $\mathrm{BAM}$. The average $\mathrm{K} / \mathrm{L}$ is 68.1 with an average growth rate of $2 \%$. A change of $2 \%$ is very small. $\mathrm{K} / \mathrm{L}$ is almost constant, so we can say that this is Hicks neutral technical progress. Labour average productivity is far greater than capital average productivity. The reason for this is a decrease in employment by a $2 \%$ average annually, a rise of real GVA by $6 \%$ on average annually, and extremely low growth of capital. Average labour productivity is 19.72 and average capital productivity is 0.31 . If we analyze marginal productivity the same conclusion is obtained. Labour is far more productive with average marginal productivity of 10.2 (median). Capital marginal productivity is 3.7 .

\section{TFP}

Total Factor Productivity (TFP) is the portion of output not explained by the amount of inputs used in production (Comin \& Hobijn \& Rovito 2006). This definition describes how important is measurement of TFP for growth, business fluctuations, for future analysis, and for policy makers. Changes in TFP, which are separate from changes in inputs, represent the joint effects of all input-augmenting technological improvements and the effect of Hicks neutral technological change (Helpman, 2004). There are many ways of measuring total factor productivity. The most often used measurements to calculate the Solow residual are Kendrick's arithmetics measure (Kendrick, 1961) and Solow's geometric index (Solow, 1957). Kendrick assumes a homogeneous production function and Euler condition to obtain the following measure (Kendrick, 1961): 
Borović Z. et al.: Measuring TFP: Growth Accounting for the Real Sector of the...

$$
\frac{d A}{A}=\frac{Q_{1} / Q_{0}}{\left(W L_{1}+r K_{1}\right) /\left(W L_{0}+r K_{0}\right)}-1
$$

Solow's measure is shown in expression 17.

The origin of the idea of the TFP existence can be found in teachings of the classical school. The strict definition and serious attempt to find a quantitative measure is recorded after 1930s. Behind this concept stands an idea that there is something else besides traditional factors of production that drives production to increase. In economic literatute this 'thing' is associated with technological progress. The TFP concept can be interpreted in many ways, but eventually it always implies that the combination of raw labour, machines, and human capital and skills leads to changes in total income that are not expected by changes in capital or labour considered separately. The TFP is very important for growth and economic fluctuations. The cross-country differences in income per capita are very often the result of cross-country differences in TFP. Kydland and Prescott (1982) initiated the real business cycle (RBC) literature based on strong correlation between TFP and output and hours worked. Robert Solow has shown in his article in 1956 that long-run growth in income per capita in an economy with an aggregate neoclassical production function must be driven by growth in TFP. The conceptual difficulty, which was present over 30 years when trying to endogenize TFP growth was how to pay for the fixed costs of innovation in a perfectly competitive economy with constant returns to scale in capital and labour. In these circumstances all output is directed to the payment of marginal products of the capital and the labour. Because of this, no resources are left to pay for the innovation costs. This problem is solved by Romer (1990) and Aghion and Howitt (1992). They granted the innovators monopolistic rights over their innovations, which are sustainable through the patent system. In this way initial fixed costs of innovation is compensated through the profit margin which they make from commercializing their patent. Link between TFP growth rate and inovation provides an insight in to the determinants of TFP growth. Grants for $R \& D$ an abundance of skilled labour will reduce the marginal cost of conducting R\&D and it will increase the rate of innovation development, and therefore the TFP growth rate. Raising innovators' revenues and market growth will lead to more innovation and higher TFP growth. In 1956 Sollow proved that cross-country differences in technology may generate important cross-country differences in income per capita. To determine the importance of these factors it is necessary to have data on direct measures of technology. The direct measures of technology adoption for approximately 75 different technologies is put together by Comin, Hobijn and Rovito (2006). Further, income per capita and technology are positively correlated. So, the crosscountry variation in TFP are highly determinated by the cross-country variation in physical technology. Generally there are three groups of 
Borović Z. et al.: Measuring TFP: Growth Accounting for the Real Sector of the...

researchers and their views of TFP are summarized in the following paragraphs (Lipsey, et al, 2001):

- One group holds that changes in TFP measure the rate of technical change. (Law, Statscan, Krugman, Young.) We refer to this as the "conventional view".

- The second group holds that TFP measures only the free lunches of technical change, which are mainly associated with externalities and scale effects (Jorgenson, and Griliches) We refer to their position as the "J\&G view.

- The third group is sceptical that TFP measures anything useful (Metcalf).

Regardless of the differing views of individual authors, TFP is carefully measured and analyzed in many countries. Thus, within the Bureau of Labour Statistics of the USA ${ }^{5}$ there is now a special section dealing with the prognosis and predicting, by analyzing the impact of employment, the workerhours and investment in the MFP (MFP or TFP) for some sectors of the economy.

Figure 1. Output per hour of all persons, multifactor productivity, and autput per unit of capital services 2000-2010.

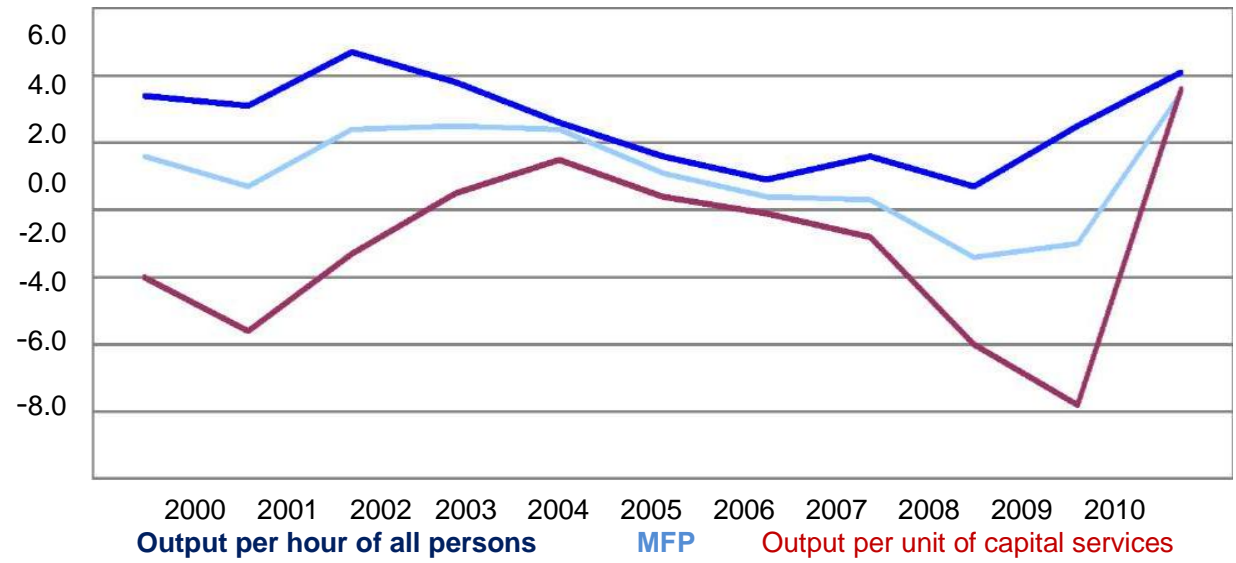

Source: http://www.bls.gov/news.release/pdf/prod3.pdf

Aghion and Howit (Aghion et al, 2007) have developed a case study for the OECD countries for the period 1960-2000. The study reached the following results for TFP growth, capital deepening, and their contribution to economic growth. The share of capital $(\alpha)$ is set to 0.3 .

\section{${ }^{5}$ http://www.bls.gov/mfp/}


Borović Z. et al.: Measuring TFP: Growth Accounting for the Real Sector of the...

Table 6. Growth accounting in OECD countries: 1960-2000.

\begin{tabular}{llcccc}
\hline Country & Growth rate & $\begin{array}{c}\text { TFP } \\
\text { growth }\end{array}$ & $\begin{array}{c}\text { Capital } \\
\text { deepening }\end{array}$ & TFP share & $\begin{array}{c}\text { Capital- } \\
\text { deepening share }\end{array}$ \\
\hline Australia & 1.67 & 1.26 & 0.41 & 0.75 & 0.25 \\
Austria & 2.99 & 2.03 & 0.96 & 0.68 & 0.32 \\
Belgium & 2.58 & 1.74 & 0.84 & 0.67 & 0.33 \\
Canada & 1.57 & 0.95 & 0.63 & 0.60 & 0.40 \\
Denmark & 1.87 & 1.32 & 0.55 & 0.70 & 0.30 \\
Finland & 2.72 & 2.03 & 0.69 & 0.75 & 0.25 \\
France & 2.50 & 1.54 & 0.95 & 0.62 & 0.38 \\
Germany & 3.09 & 1.96 & 1.12 & 0.64 & 0.36 \\
Greece & 1.93 & 1.66 & 0.27 & 0.86 & 0.14 \\
Iceland & 4.02 & 2.33 & 1.69 & 0.58 & 0.42 \\
Ireland & 2.93 & 2.26 & 0.67 & 0.77 & 0.23 \\
Italy & 4.04 & 2.10 & 1.94 & 0.52 & 0.48 \\
Japan & 3.28 & 2.73 & 0.56 & 0.83 & 0.17 \\
Netherlands & 1.74 & 1.25 & 0.49 & 0.72 & 0.28 \\
New Zealand & 0.61 & 0.45 & 0.16 & 0.74 & 0.26 \\
Norway & 2.36 & 1.70 & 0.66 & 0.72 & 0.28 \\
Portugal & 3.42 & 2.06 & 1.36 & 0.60 & 0.40 \\
Spain & 3.22 & 1.79 & 1.44 & 0.55 & 0.45 \\
Sweden & 1.68 & 1.24 & 0.44 & 0.74 & 0.26 \\
Switzerland & 0.98 & 0.69 & 0.29 & 0.70 & 0.30 \\
United Kingdom & 1.90 & 1.31 & 0.58 & 0.69 & 0.31 \\
United States & 1.89 & 1.09 & 0.80 & 0.58 & 0.42 \\
Average & 2.41 & 1.61 & 0.80 & 0.68 & 0.32 \\
\hline
\end{tabular}

Source: Aghion, et al, 2007.

Data for OECD countries suggest that TFP contributes much more to economic growth then capital deepening. The average contribution of TFP for the period amounted to $68 \%$, while the contribution of capital deepening is $32 \%$.

\section{Results for the RS}

The calculations with respect to total factor productivity for the real sector have been made for the period 2004-2010. The first problem was to estimate the capital stock. In our work we have used a PIM method which involves investment and depreciation rate. Due to lack of data on depreciation rate we have estimated the rate of depreciation to be $5 \%$ per year. The PIM method involves expression (14) to calculate the initial capital stock. To calculate the initial capital we applied expression (16). Applying expression (14) implies a sufficiently long time series for investment. The time series available to us are limited to the period 2004-2010. Applying expression (14) we obtain a level of initial capital which is higher than the level obtained applying expression (16). The economy in the RS is at a very low level of activity and the analyzed data 
Borović Z. et al.: Measuring TFP: Growth Accounting for the Real Sector of the...

indicates that the real sector of the economy is slowing down. For this reason we used expression (16).

The second problem was to estimate the share of labour in the distribution of GVA (GDP). Applying expressions (12) we obtain useless results. The analyzed data shows that the share of labour $(1-\alpha)$ is set to 0.04 on average for period 2004-2010. One reason for this is the very low price of labour because of the high unemployment rate $(36.5 \%$ for the period $2004-2010$; $37.3 \%$ in $2010^{6}$ ). The actual unemployment rate is lower due to the existence of the grey economy. The high unemployment rate indicates that the supply of labour exceeds the demand for labour. Due to the higher supply, the price of labour is very low. But in the last couple of years the government has raised taxes and this makes labour more expensive. Because of higher taxes many employers are trying to reduce labour costs by reducing wages and the number of workers, or they show incorrect data about the number of workers, their education, and their salaries. Even so, it is not normally and economically logical that labour is underestimated like this. The second reason is that analyzed data published by the $R S$ Institute of Statistics are incorrect. Incorrect data can be the result of incorrect publishing, or the collected data were incorrect and do not reflect the real state of things, which is more likely. To estimate the share of labour, we use the expression (13). For the real sector of the RS share of labour is 0.4. For USA and OECD countries share of labour is estimated at 0.7 (Aghion, et al, 2007). For Russian Federation share of labour is estimated at 0.62 for total economy and 0.57 for manufacturing (Simon, 2010). For Romania and Moldova share of labour is estimated at 0.47 and 0.37 respectively for period 2002-2004 (Zaman, et al, 2007). For Bulgaria share of labour is set to 0.3 for period 1998-2001 (Ganev, 2005,). In many analyses it is standard to estimate share of labout to approximately $2 / 3$, or 0.66 . The logic would be that it is hard to believe that the production function is fundamentally different from other countries, and the parameter alpha is a parameter of the production function. Similarly, when we look at cross country data, we assume that all countries have the same capital and labor exponents in the production function. ${ }^{7}$ This assumption is met in many countries mentioned above. But, this assumption is not valid in other countries as former Socialistic countries (Bulgaria, Moldova and Romania). RS is former Socialistic country which is in transition to market economy. Before becoming EU members, Bulgaria and Romania had share of labour at 0.3-0.4. It is same for Moldova.

The analysis of the contributions of labour, capital, and technical progress to economic growth for the real sector in RS is given in Tables 6 and 7.

\footnotetext{
${ }^{6}$ http://www.irbrs.net/Statistika.aspx?tab=1\&lang=cir

7 This conclusion is result of consultations with professor David Weil.
} 
Borović Z. et al.: Measuring TFP: Growth Accounting for the Real Sector of the...

Table 7. Growth accounting for the real sector in $R S$

\begin{tabular}{|c|c|c|c|c|}
\hline Years & $\begin{array}{c}\text { Real growth rate for } \\
\text { real sector }\end{array}$ & $\alpha^{*}(\Delta \mathrm{K} / \mathrm{K})$ & $(1-\alpha)^{*}(\Delta \mathrm{L} / \mathrm{L})$ & TFP \\
\hline 2004 & & & & \\
\hline 2005 & 0.20 & 0.0048 & -0.0099 & 0.2056 \\
\hline 2006 & 0.08 & -0.0011 & -0.0261 & 0.1035 \\
\hline 2007 & -0.04 & 0.0029 & 0.0005 & -0.0443 \\
\hline 2008 & 0.12 & 0.0117 & 0.0541 & 0.0552 \\
\hline 2009 & -0.03 & 0.0102 & -0.0116 & -0.0286 \\
\hline 2010 & -0.01 & 0.0046 & -0.0357 & 0.0211 \\
\hline Average & 0.0528 & 0.01 & -0.0048 & 0.052 \\
\hline
\end{tabular}

Source: Author's calculations

Table 8. Capital deepening and TFP for the real sector in RS

\begin{tabular}{|r|c|r|r|r|r|}
\hline Years & $\begin{array}{c}\text { Growth rate of } \\
\text { labour productivity in } \\
\text { real sector }\end{array}$ & TFP & \multicolumn{1}{c|}{$\begin{array}{c}\text { Capital } \\
\text { deepening }\end{array}$} & \% TFP & $\begin{array}{r}\text { \% Capital } \\
\text { deepening }\end{array}$ \\
\hline 2004 & & & & & \\
\hline 2005 & 0.23 & 0.1938 & 0.0315 & 0.8602 & 0.1398 \\
\hline 2006 & 0.14 & 0.1035 & 0.0381 & 0.7308 & 0.2692 \\
\hline 2007 & -0.04 & -0.0443 & 0.0021 & 1.0506 & -0.0506 \\
\hline 2008 & 0.15 & 0.0552 & -0.0695 & -3.8736 & 4.8736 \\
\hline 2009 & -0.001 & -0.0286 & 0.0277 & 29.5069 & -28.5069 \\
\hline 2010 & 0.08 & 0.0211 & 0.0581 & 0.2664 & 0.7336 \\
\hline Average & 0.06 & 0.05 & 0.01 & 0.77 & 0.23 \\
\hline
\end{tabular}

Source: Author's calculations

\section{Discussion and Conclusions}

The analyzed data clearly indicate that the TFP is the driving force behind growth in the production volume of the real sector in the RS. Table 7 shows that the average growth rate of real GVA is on average $5 \%$ per year and the largest contributor to growth is TFP with an average growth of $5 \%$ per year, 
followed by a capital contribution of $1 \%$ on average annually. The correlation between TFP and growth rate is positive and very high at 0.93 and determination coefficient is set at 0.87 (87\%). The average growth rate of TFP is the same as the growth rate of real GVA. This only proves that TFP is the driving force behind growth in production volume of the real sector in the RS. The labour contribution throughout the period is mostly negative. This is the result of an almost constant decrease in the number of employees in the real sector. On average Sector $D$ employment fell by $3 \%$ annually. Capital in the reporting period decreased more rapidly than it grew. The depreciation rate is $5 \%$, while the growth rate of investment in the real sector was only $0.8 \%$ on average annually. For this reason it is an extremely small contribution the capital. TFP achieved negative values in two years. In 2007 there was a negative real rate of growth of $4 \%$. In the same year there was very low but positive contribution of labour and capital. Mathematically TFP had to be negative. The year 2007 is characterised by a high inflation rate of $23 \%$ compared to 2001 . Put simply, prices were rising faster than production volume in the real sector. Also in 2010 TFP was negative. As in the previous case the reason for this lies in the extremely high inflation rate of $34 \%$ compared to 2001, the negative contribution of labour and the reduction in the overall production volume of the real sector. However, in some years there has been a negative contribution of labour and capital, and in the same years the real sector recorded significant growth rates. TFP, i.e., technical progress, is most responsibile for the realized growth rates and for the extremely low rate of decrease in real growth, despite a very small contribution of capital and often negative contribution of labour. Similar conclusions can be made by analyzing Table 8 . Labour productivity grew at a rate of $6 \%$ on average annually. The participation of technical progress in this growth is $77 \%$ on average annually. The participation of capital deepening in labour productivity growth is $23 \%$ on average annually. Growth in labour productivity and capital deepening is not the result of the increase in volume of capital: it is simply a result of a decreasing number of employees. The analysis shows that the real growth in the real sector is not result of capital or labour. We conclude that technical progress is most responsible for the increase in real GVA and labour productivity growth. If we compare RS with OECD countries, the real sector of the RS achieved higher rates of real growth and a far more significant contribution of TFP growth in the real sector in the RS. Conclusions based on these data are wrong. It is impossible to compare only certain sectors of the economy with the economy of other countries. The conclusions would not be valid.

It is important to note that the calculation of TFP and its contribution to real growth of the real sector probably does not reflect the real situation. The reason for this is a very short period for analysis, the lack of data on actual rates of depreciation and errors that can occur in the assessment of initial 
Borović Z. et al.: Measuring TFP: Growth Accounting for the Real Sector of the...

capital. Also, the official statistics do not take into account the "gray economy". There have been many attempts to assess the extent of the gray economy in the RS. It is certain that the results would be more valid if this part of the economic activity activities were taken into account.

Table 5 shows an increase in labour productivity. This conclusion is wrong. The number of workers in the real sector is decreasing, $\mathrm{K} / \mathrm{L}$ is almost constant, and capital productivity is very low. The driving force behind real growth must be TFP, or, the data on real GVA do not reflect the true state of things.

Investment in the real sector is the basis for new jobs, an increase in productivity, reduced costs, increased competition, lower prices, and real growth in living standards. Negative trends in employment and investment were present throughout the decade and the government does nothing to change that. The currency board and constant borrowing in order to ensure the functioning of the bureaucracy provides RS with fiscal stability. Huge funds from international lending institutions were used for final consumption and not for investment in the real sector. Based on the current model, if the government manages to ensure stable growth of the contribution of labour by $1 \%$ per year on average and capital by $2 \%$ on average annually in the real sector, it can expect a real growth rate of the real sector of $7 \%$ on average annually. This would mean employment growth of $2.5 \%$ and capital growth of $3 \%$. If the government does nothing, then the economic system of the RS will crumble under the pressure of the obligations arising from new debts that are used for final consumption and to settle outstanding obligations to international institutions.

Our model indicates that TFP is the main driving force behind the real growth in the real sector in the RS. In the preceding section we have expressed doubt as to the accuracy of the model due to the existing objective limitations. The question is, what drives real growth? The authors of these lines express doubts about the methodology for calculation of macroeconomic aggregates for the RS. The suspicion is based on the fact that all macroeconomic variables are growing whenever the RS a takes loan. According to official statistics growth in real GDP in the last ten years is approximately $12 \%$ on average annually. This data is incorrect. First, because this growth rate incorporates CPI for the previous year, and second, to achieve this growth rate it takes constantly increasing net investments and employment in the real sector. If this data is true, then workers in the real sector should have aboveaverage purchasing power and the domestic market should be overrun with local products. Unfortunately, the situation is completely different. The economy in the RS is full of anomalies. The distribution of the condition of economics activity is not productive, and does not contribute to the growth of the real sector. Government spends on bureaucracy rather than on the real 
Borović Z. et al.: Measuring TFP: Growth Accounting for the Real Sector of the...

sector and real production. The growth was funded mainly through the final consumption of imported products which are bought with foreign assets, rather than through our own production.

The growth of TFP is triggered by high investment in education and science and technology. In the RS, science and technology in the last five years stands at an average 4\% of GDP with a tendency to decrease (Ministry of Science and Technology). The number of highly educated is growing from year to year, but the structure of highly educated workers is extremely unfavourable. In the last five years about $75 \%$ of graduates heve been in in social sciences, and less than $10 \%$ in engineering ${ }^{8}$. A major problem is the so-called. "brain drain". Estimates are that the more highly educated young workers from technical professions have abandoned the RS because of poor work conditions or no at all. All this represents a significant problem that slows down the actual growth of TFP which should be urgently addressed.

This survey is one of the first papers on this subject in our country. In the research we have not met all the assumptions of the model and it is likely that the estimates of capital are not very accurate, and therefore TFP estimates do not reflect the real state of things. Despite these shortcomings the conducted research can make a significant contribution to the analysis of the real sector in the RS and the contribution of labour, capital. and TFP to this sector. This paper can also provide a significant basis for future analysis and assessment of developments in the real sector with scientific and practical aspects. The authors hope that the economic policy makers will pay more attention to the real sector of the RS for the benefit of all citizens.

\section{Reference}

Aghion, P., \& Howit, P. (1992). A Model of Growth Through Creative Destruction. Econometrica, 60(2), 323-351.

Aghion, P., \& Howit, P. (2007). Capital, innovation, and growth accounting. Oxford Review of Economic Policy, 23(1), 79-93.

Burda, C.M., \& Severgnini, B. (2008). Solow Residuals without Capital Stocks. Berlin: Humboldt-Universität zu Berlin.

Comin, D. (2006). Total Factor Productivity. In C.R. Braun \& J. Segura (Eds.), An Eponymous Dictionary of Economics. Elgar Publishers, Ltd.

Comin, D., Hobijn, B., \& Rovito, E. (2006). Five Facts You Need to Know About Technology Diffusion.

Cororaton, C. (2002). Total Factor Productivity in the Philippines. Philippine Institute for Development Studies.

Felipe, J. (1997). Total Factor Productivity Growth in East Asia: A Critical Survey. Asian Development Bank.

${ }^{8}$ http://rzs.rs.ba/PublikObrazCIR.htm

Industrija, Vol.41, No.3, 2013 
Borović Z. et al.: Measuring TFP: Growth Accounting for the Real Sector of the...

Ganev, K. (2005). Measuring total factor productivity: Growth accounting for Bulgaria. Bulgarian National Bank.

Goldsmith, R. (1955). The National Wealth of the United States in the Post-war Period. Princeton, N. J.: Princeton University Press.

Gomme, P., \& Rupert, P. (2004). Measuring labours share of income. Federal reserve Bank of Cleveland.

Helpman, E. (2004). The mystery of economic growth. London: Harvard University Press.

Hernandez, J.A., \& Mauleon, I. (2003). Estimating the Capital Stock. Universidad de la Laguna; Universidad de Las Palmas de Gran Canaria.

Kendrick, J. (1961). Productivity trends in the United States. Princeton: Princeton University Press.

Kydland, F., \& Prescott, E. (1982). Time to Build and Aggregate Fluctuations. Econometrica, 50(6), 1345-1370.

Leković, V., \& Mićić, V. (2013). Needs, effectiveness and limitations of the industrial policy of Serbia. Industrija, 41(1), 5-30. doi:10.5937/industrija41-3414

Lipsey, R., \& Carlaw, K. (2001). What does total factor productivity measure. Simon Fraser University at Harbour Centre.

Ministry of Science and Technology, Republic of Srpska.

Petrović, P. (2012). Openness and growth: Empirical research on the case of Serbia. Industrija, 40(1), $173-190 . \quad$ Retrieved from http://scindeks.ceon.rs/article.aspx?artid=0350-03731201173P

Romer, P. (1990). Endogenous Technological Change. Journal of Political Economy, 98(5),

Simon, G.J. (2010). Technical progress and its factors in Russia's economy. Ekonomski anali, 55(186), 7-41. doi:10.2298/EKA1086007S

Solow, R. (1956). A Contribution to the Theory of Economic Growth. Quarterly Journal of Economics, 70(1), 65-94.

Solow, R. (1957). Technical Change and the Aggregate Production Function. Review of Economics and Statistics, 39, 312-320.

Zaman, G., Goschin, Z., \& Partachi, I. (2007). The contribution of labour and capital to Romania's and Moldova's economic growth. Journal of applied quantitative methods, 2(1), 179-185. 